Received 30.01.2017 Reviewed 13.04.2017 Accepted 16.05.2017

A - study design

B - data collection

C - statistical analysis

D - data interpretation

$\mathbf{E}$ - manuscript preparation

F - literature search

\title{
Studying the effect of a variation \\ in the main parameters on stability of homogeneous earth dams using design experiment
}

\author{
Rida LAKEHAL ${ }^{\text {ABCDEF } ₫}{ }^{\text {Lakhdar DJEMILI }}{ }^{\text {AD }}$
}

Badji Mokhtar University, Department of Hydraulic, Annaba, BP 12, 23000, Algeria; e-mail: lakehal@hotmail.fr, lakhdardjemili@hotmail.com

For citation: Lakehal R., Djemili L. 2017. Studying the effect of a variation in the main parameters on stability of homogeneous earth dams using design experiment. Journal of Water and Land Development. No. 34 p. 173-179. DOI: $10.1515 /$ jwld-2017-0051.

\begin{abstract}
Deterministic approaches such as the limit equilibrium method (LEM) especially Bishop modified method has been traditionally used to evaluate the stability of embankment dams. However, the uncertainty associated with the material properties necessitates the use of the probabilistic method to account the sensitivity of this uncertainty on the response of the deterministic approaches. In this study, the authors propose the application of design experiment, especially central composite design (CCD) to determine the effects of independent uncertain parameters on the response of stability. A second-order polynomial model with cross terms is used to create an approximating function referred to as response surface for the implicit limit state surface, for which the input data were provided by stability analyses of different heights of homogeneous earth dams (10 m, $20 \mathrm{~m}$, and $30 \mathrm{~m})$ with a depth ratio of $D H=1.5$ and a circular slip surface using the Bishop modified limit equilibrium method. The proposed models obtained from this application represent higher prediction accuracy. The study of the effect of geotechnical parameters (material properties of embankment) on safety factor show the importance of individual factors in level of linear effect with a positive effect of $c^{\prime}$ or $\varphi^{\prime}$ and a negative effect of $H, \gamma_{d}, \gamma_{\text {sat }}$ and significant influence of two-factors interaction, the effect of $c^{\prime}$ highly dependent on $H, \beta, \gamma_{d}$ and $\varphi$ '. Moreover, the effect of $\varphi^{\prime}$ is dependent on the values of $H$ and $\beta$. Lastly, the optimization of safety factor with respect to the range of values of material properties was made, and two failures modes are discussed which are $\left(\varphi^{\prime}, c^{\prime}\right.$ reduction and $\gamma_{d}$ increase).
\end{abstract}

Key words: design experiment, homogeneous earth dam, safety factor, stability analysis

\section{INTRODUCTION}

The limit equilibrium method is the most popular approach in slope stability analysis. This method is well known to be a statically indeterminate problem, and assumptions on the inter-slice shear forces are required to make the problem statically determinate. Based on the assumptions of the internal forces and force and moment equilibrium, there are more than ten methods developed for slope stability analysis. The famous methods include those by FELLENIUS
[1936], JANBU [1954], BISHOP [1955] and JANBU [1973]. In recent years, because the uncertainty associated with stability analysis especially material proprieties the using of the probabilistic approaches is required to account the sensitivity of this uncertainty on the response of the deterministic approaches. Accordingly, many studies have been taken to develop a probabilistic slope stability analysis that deal with the uncertainties of soil proprieties in systematic way [Alonso 1976; Cheng et al. 2008; De Mello 1977]. 
WONG [1985] performed reliability analysis of soil slopes using response surfaces method (RSM). HUMPHREYS and ARMSTRONG [1993] analysed a slope stability problem using results of finite difference method and regression analysis. TANDJIRIA et al. [2000] used response surface method for reliability analysis of laterally loaded piles. SIVAKUMAR BABU and SRIVASTAVA [2007] presented a study on the analysis of allowable bearing pressures on shallow foundation using response surface method. In many practical probabilistic problems, the response function is not known explicitly. Instead, it may be known only implicitly through a numerical procedure. Therefore, the failure domain only can be found through repeated point by point numerical analyses with different input values. To reduce the computational effort required for the probabilistic analyses, a response surface that approximate the limit state function through polynomial regression for the results of several selected simulations is needed. Kostić et al. [2016] presented new approach to approximate the limit state function for the stability analysis using Box-Behnken statistical design integrate with limit equilibrium methods (LEM).

In the current study the procedure for probabilistic analysis of the stability of homogenous earth dam is proposed using design experiments. The limit state surface function of safety factor was conducted by central composite design (CCD) technics based on the limit equilibrium method (LEM) especially Bishop modified method using the commercial software GEOSTAB [GEOS 2004]. The data sets used for the construction of response surface are obtained from stability analyses of six cases of homogeneous earth dams situated in eastern Algeria. The primary objective of this study is to determine the effect of geotechnical parameters (material proprieties of embankment) on the safety factor of homogeneous earth dams with known geometric designs [TERZAGHI, PECK 1965]. Finally, discussion of the obtained results and main conclusions are given for taken account in other researches in this field.

\section{METHODS AND MATERIALS}

\section{LIMIT EQUILIBRIUM METHOD (MODIFIED BISHOP'S METHOD)}

BISHOP [1955] made a more reasonable assumption on the side forces by assuming that the shear forces on the side of each slice are zero. Although this assumption is only an approximation to the truth, it is much better than the assumption used in the ordinary method of slice [ALONSO 1976; HAMMURI et al. 2008; USACE 2003]. The resulting method based on this assumption is called the modified Bishop's method or the simplified Bishop's method. For a homogenous soil slope, the slope failure is dominated by the deterministic critical slip surface because the factors of safety $F s$ of other slip surfaces are highly correlated with the $F s$ of the deterministic critical slip surface.

\section{DESIGN EXPERIMENT (CENTRAL COMPOSITE DESIGN - CCD)}

In statistics, a central composite design is an experimental design, useful in response surface methodology, for building models, evaluating the effects of factors and searching for the optimum conditions for the response variable without needing to use a complete three-level factorial experiment; this technique has been successfully used in slope stability analysis. A prior knowledge and understanding of the process and the process variables under investigation are necessary for achieving a more realistic model. In this study, CCD is performed to estimate the performance function of the quadratic model for optimizing the process. The independent variables are transformed into code level range from -1 to +1 interval where the low and high levels code as -1 and +1 , respectively. The axial points are located at the value of $+\alpha$ and $-\alpha$ where $\alpha$ is the distance of the axial point from the centre and performs the design rotatable in this study we use the characteristic of face cantered star point, the centre points coded as 0 . In this study a $2^{(m)}+2 *(m)$, two levels; $(m)$ variable were used, for two variables, the model obtained was expressed as follows:

$$
Y=a_{0}+a_{1} X_{1}+a_{2} X_{2}+a_{11} X_{11}^{2}+a_{22} X_{22}{ }^{2}+a_{12} X_{12}
$$

where: $Y=$ the measured response, $a_{0}=$ the intercept term, $a_{1}, a_{2}=$ linear coefficients, $a_{12}=$ the logarithmic coefficient, $a_{11}, a_{22}=$ quadratic coefficients, $X_{1}, X_{2}=$ coded independent variables.

The statistical analysis of the model was performed in the form of Analysis of Variance (ANOVA).

\section{LONG-TERM STABILITY ANALYSIS AND DESIGN EXPERIMENT}

In the eastern of Algeria, the construction of homogeneous earth dams increased in last years, especially in areas dominated by agriculture. By considering the questions of security, it is absolutely necessary to study their stability in the various cases of loading especially in long-term case [LAKEHAL et al. 2011].

Limit equilibrium method (modified Bishop's method) linking with design experiment (central composite design), was applied to estimate the effect of main geotechnical parameters on safety factor of homogenous earth dams with a geometric designs of a different heights and slope angle $\left(10 \mathrm{~m}, \beta=22^{\circ}\right)$, $\left(20 \mathrm{~m}, \beta=18^{\circ}\right),\left(30 \mathrm{~m}, \beta=16^{\circ}\right)-$ Table 1 [TERZAGHI, PECK 1965]. The thickness of foundation in the site of study is varied between $5 \mathrm{~m}$ at $15 \mathrm{~m}$, we take the values of 5,10 and $15 \mathrm{~m}$ for three profile of embankments respectively in which the depth to bedrock $D H$ equal 1.5 in this study. Figure 1 shows the profile type 
Table 1. Design experiment of 4 factors (geotechnical parameters with differents geometric designs), $2^{(4)}+2 *(4)$ central composite design, runs $=27$

\begin{tabular}{|c|c|c|c|c|c|c|c|c|}
\hline \multirow{2}{*}{ Runs } & \multirow{2}{*}{ Block } & \multirow{2}{*}{$c^{\prime}$} & \multirow{2}{*}{$\varphi^{\prime}$} & \multirow{2}{*}{$\gamma_{d}$} & \multirow{2}{*}{$\gamma_{\text {sat }}$} & \multicolumn{3}{|c|}{$F s$} \\
\cline { 7 - 9 } & & & & & & & \multicolumn{3}{|c|}{${ }^{\prime}$} \\
\hline 4 & 1 & 12.00000 & 20.00000 & 19.20000 & 21.20000 & 1.758 & 1.463 & 1.419 \\
\hline 8 & 1 & 30.00000 & 20.00000 & 19.20000 & 20.00000 & 1.967 & 1.591 & 1.525 \\
\hline 14 & 2 & 30.00000 & 11.00000 & 16.20000 & 21.20000 & 1.937 & 1.453 & 1.352 \\
\hline 16 & 2 & 30.00000 & 20.00000 & 16.20000 & 20.00000 & 2.088 & 1.619 & 1.524 \\
\hline 13 & 2 & 12.00000 & 20.00000 & 19.20000 & 20.00000 & 1.768 & 1.478 & 1.440 \\
\hline 26 & 3 & 21.00000 & 16.16000 & 17.60000 & 21.20000 & 1.852 & 1.465 & 1.395 \\
\hline 6 & 1 & 30.00000 & 11.00000 & 19.20000 & 21.20000 & 1.811 & 1.420 & 1.339 \\
\hline 10 & 2 & 12.00000 & 11.00000 & 16.20000 & 20.00000 & 1.479 & 1.282 & 1.188 \\
\hline 1 & 1 & 12.00000 & 11.00000 & 16.20000 & 21.20000 & 1.479 & 1.282 & 1.185 \\
\hline 11 & 2 & 12.00000 & 11.00000 & 19.20000 & 21.20000 & 1.364 & 1.188 & 1.132 \\
\hline $27(\mathrm{C})$ & 3 & 21.00000 & 16.16000 & 17.60000 & 20.78300 & 1.859 & 1.473 & 1.403 \\
\hline 24 & 3 & 21.00000 & 16.16000 & 19.20000 & 20.78300 & 1.799 & 1.460 & 1.402 \\
\hline 21 & 3 & 21.00000 & 11.00000 & 17.60000 & 20.78300 & 1.767 & 1.378 & 1.292 \\
\hline 12 & 2 & 12.00000 & 20.00000 & 16.20000 & 21.20000 & 1.861 & 1.481 & 1.415 \\
\hline $18(\mathrm{C})$ & 2 & 21.00000 & 16.16000 & 17.60000 & 20.78300 & 1.859 & 1.473 & 1.403 \\
\hline 3 & 1 & 12.00000 & 20.00000 & 16.20000 & 20.00000 & 1.881 & 1.502 & 1.438 \\
\hline 23 & 3 & 21.00000 & 16.16000 & 16.20000 & 20.78300 & 1.915 & 1.486 & 1.404 \\
\hline 17 & 2 & 30.00000 & 20.00000 & 19.20000 & 21.20000 & 1.948 & 1.568 & 1.496 \\
\hline 19 & 3 & 12.00000 & 16.16000 & 17.60000 & 20.78300 & 1.675 & 1.407 & 1.352 \\
\hline 25 & 3 & 21.00000 & 16.16000 & 17.60000 & 20.00000 & 1.873 & 1.488 & 1.419 \\
\hline 7 & 1 & 30.00000 & 20.00000 & 16.20000 & 21.20000 & 2.057 & 1.588 & 1.493 \\
\hline 15 & 2 & 30.00000 & 11.00000 & 19.20000 & 20.00000 & 1.817 & 1.441 & 1.361 \\
\hline $9(\mathrm{C})$ & 1 & 21.00000 & 16.16000 & 17.60000 & 20.78300 & 1.859 & 1.473 & 1.403 \\
\hline 5 & 1 & 30.00000 & 11.00000 & 16.20000 & 20.00000 & 1.962 & 1.481 & 1.377 \\
\hline 2 & 1 & 12.00000 & 11.00000 & 19.20000 & 20.00000 & 1.364 & 1.188 & 1.135 \\
\hline 22 & 3 & 21.00000 & 20.00000 & 17.60000 & 20.78300 & 1.924 & 1.538 & 1.468 \\
\hline 20 & 3 & 30.00000 & 16.16000 & 17.60000 & 20.78300 & 1.963 & 1.537 & 1.448 \\
\hline
\end{tabular}

Explanations: $c^{\prime}=$ cohesion $(\mathrm{kPa}), \varphi^{\prime}=$ friction angle $\left(^{\circ}\right), \gamma_{d}=$ dry density $\left(\mathrm{kN} \cdot \mathrm{m}^{-3}\right), \gamma_{\text {sat }}=$ saturated density $\left(\mathrm{kN} \cdot \mathrm{m}^{-3}\right), H=$ height, $\beta=$ slope angle.

Source: own study.

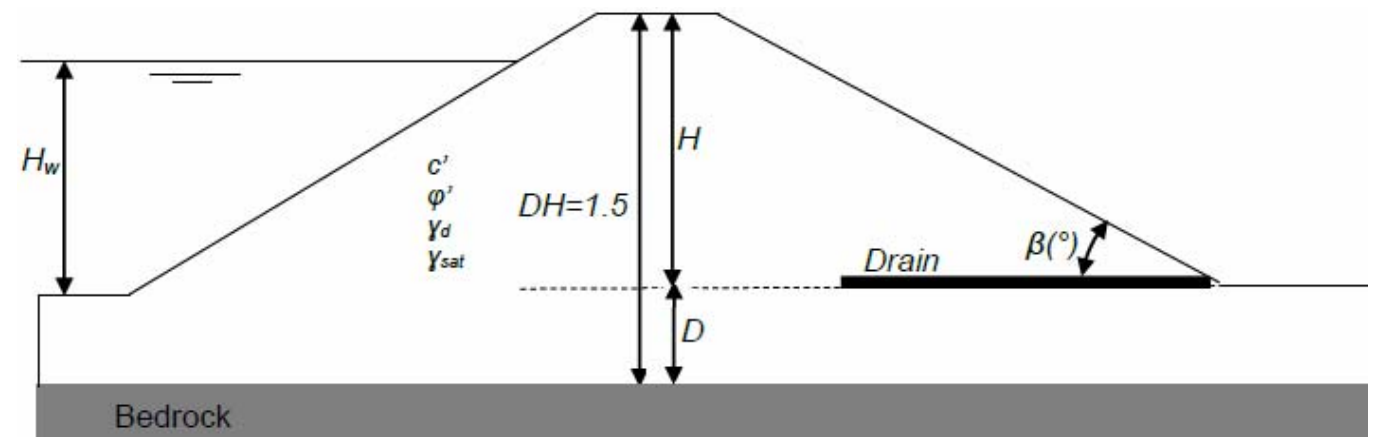

Fig. 1. Profile type of homogenous earth dam; source: own elaboration

used in the simulation process by GEOSTAB software [LAKEHAL et al. 2011].

In this study, a set of input and output data are prepared, and a central composite design CCD is used for developing the function of the quadratic model, the effect of variation of materials proprieties are studied witch are: cohesion $\left(c^{\prime}\right)$, friction angle $\left(\varphi^{\prime}\right)$, dry density $\left(\gamma_{d}\right)$ and saturated density $\left(\gamma_{\text {sat }}\right)$. All data selected for developing the function of the quadratic model are obtained from stability analyses of ten cases of homogenous earth dams situated in eastern of Algeria based on the limit equilibrium method especially Bishop modified method using the commercial software GEOSTAB 4.0.
The range values of geotechnical properties of construction materials are given in Table 2. The experimental design of the independent variables in terms the actual and coded values with height and low level are listed in Table 3.

Table 2. Range values of geotechnical properties of construction materials in eastern of Algeria

\begin{tabular}{|l|c|}
\hline \multicolumn{1}{|c|}{ Parameter } & Range \\
\hline Cohesion $c^{\prime}, \mathrm{kPa}$ & $12-30$ \\
\hline Friction angle $\varphi^{\prime},{ }^{\circ}$ & $11-20$ \\
\hline Dry density $\gamma_{d}, \mathrm{kN} \cdot \mathrm{m}^{-3}$ & $16.2-19.2$ \\
\hline Saturated density $\gamma_{\mathrm{sat}}, \mathrm{kN} \cdot \mathrm{m}^{-3}$ & $20-21.2$ \\
\hline
\end{tabular}

Source: own study. 
Table 3. Experimental design of the independent variables in terms the actual and coded values

\begin{tabular}{|l|c|c|c|}
\hline \multirow{2}{*}{ Parameter } & \multicolumn{3}{c|}{ Actual and coded values } \\
\cline { 2 - 4 } & low level & centre point & high level \\
\hline Variables & -1 & 0 & +1 \\
\hline Cohesion $c^{\prime}, \mathrm{kPa}$ & 12 & 21 & 30 \\
\hline Friction angle $\varphi^{\prime},{ }^{\circ}$ & 11 & 16.16 & 20 \\
\hline Dry density $\gamma_{d}, \mathrm{kN} \cdot \mathrm{m}^{-3}$ & 16.2 & 17.60 & 19.2 \\
\hline Saturated density $\gamma_{\text {sat }}, \mathrm{kN} \cdot \mathrm{m}^{-3}$ & 20 & 20.783 & 21.2 \\
\hline
\end{tabular}

Source: own study.

\section{RESULTS AND DISCUSSION}

In this study the problem is considered a singlelayered homogenous soil slope, thus, the quadratic response surface provides a reasonably accurate estimate of slope failure probability and has a high computational efficiency [DIAN-QIANG et al. 2016].

The quadratic response surface equation for safety factor with respect to the original variables was expressed as follows:

$F s_{H=10 \mathrm{~m}}=0.9+7.11 \cdot 10^{-2} c^{\prime}-6.6 \cdot 10^{-4} c^{2}+6.21 \cdot 10^{-2}$ $\varphi^{\prime}-3.94 \cdot 10^{-2} \gamma_{d}-1.6 \cdot 10^{-3} c^{\prime} \varphi^{\prime}$

$F s_{H=20 \mathrm{~m}}=1.68+9.77 \cdot 10^{-3} c^{\prime}+3.61 \cdot 10^{-2} \varphi^{\prime}-5 \cdot 10^{-2} \gamma_{d}$ $-1.4 \cdot 10^{-2} \gamma_{\text {sat }}-6.42 \cdot 10^{-4} c^{\prime} \varphi^{\prime}+5.11 \cdot 10^{-4} c \gamma_{d}+$ $1.62 \cdot 10^{-3} \varphi^{\prime} \gamma_{d}-9.78 \cdot 10^{-4} \varphi^{\prime 2}$

$F s_{H=30 \mathrm{~m}}=1.14+1.87 \cdot 10^{-2} c^{\prime}+5.17 \cdot 10^{-2} \varphi^{\prime}-2.62 \cdot 10^{-}$ ${ }^{2} \gamma_{d}-1.59 \cdot 10^{-2} \gamma_{\text {sat }}-7.21 \cdot 10^{-4} c^{\prime} \varphi^{\prime}+1.37 \cdot 10^{-3} \varphi^{\prime} \gamma_{d}-$ $1.22 \cdot 10^{-3} \varphi^{, 2}$
As shown in Table 4, the adjusted $R$ coefficient was in the range of 0.987 to 0.990 and the standard deviation was 0.02 for the three response surfaces models of safety factor. The obtained $R^{2}$ value was fairly high; even close to the unity and the smaller value of standard deviation indicating that there exists a close match between the experimental and the predicted values from the obtained response surface models (Fig. 2).

Table 4. Results of ANOVA analysis of the significant terms model

\begin{tabular}{|c|c|c|c|}
\hline \multirow{3}{*}{ Parameter } & $\begin{array}{c}H=10 \mathrm{~m} \\
\beta=22^{\circ}\end{array}$ & $\begin{array}{c}H=20 \mathrm{~m} \\
\beta=18^{\circ}\end{array}$ & $\begin{array}{c}H=30 \mathrm{~m} \\
\beta=16^{\circ}\end{array}$ \\
\cline { 2 - 4 } & \multicolumn{3}{|c|}{$p$-value } \\
\hline$c^{\prime}$ & $<0.0001$ & $<0.0001$ & $<0.0001$ \\
\hline$\varphi^{\prime}$ & $<0.0001$ & $<0.0001$ & $<0.0001$ \\
\hline$\gamma_{d}$ & $<0.0001$ & $<0.0001$ & 0.0207 \\
\hline$\gamma_{\text {sat }}$ & & 0.0117 & 0.0036 \\
\hline$c^{\prime} \varphi^{\prime}$ & $<0.0001$ & $<.0 .0001$ & $<.0 .0001$ \\
\hline$c^{\prime} \gamma_{d}$ & $/$ & 0.0454 & $/$ \\
\hline$\varphi^{\prime} \gamma_{d}$ & $/$ & 0.0031 & 0.0071 \\
\hline$c^{\prime 2}$ & $<0.0001$ & $/$ & $/$ \\
\hline$\varphi^{\prime 2}$ & $/$ & 0.0019 & 0.0001 \\
\hline Model $F$ value & 513.88 & 231.68 & 281.88 \\
\hline$R^{2}$ & 0.99 & 0.99 & 0.99 \\
\hline Adj $R$ & 0.98 & 0.98 & 0.98 \\
\hline Pure error & 0.000 & 0.000 & 0.000 \\
\hline
\end{tabular}

Explanations: $c^{\prime}, \varphi^{\prime}, \gamma_{d}, \gamma_{\text {sat }} H, \beta$ as in Table $2, R^{2}=$ coefficient of determination.

Source: own study.
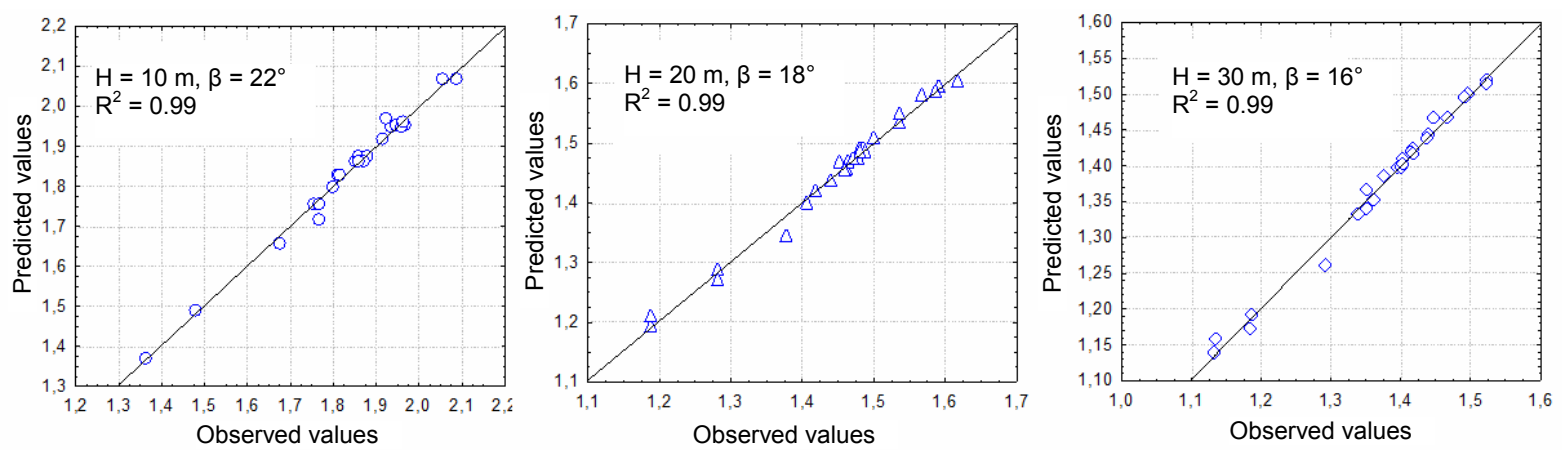

Fig. 2. Observed and predicted values from the obtained response surface models; $H=$ height, $\beta=$ slope angle, $R^{2}=$ coefficient of determination; source: own study

The accuracy of the model was further justified through analysis of variance (ANOVA). For the three response surfaces models of safety factor, their $F$-values of 230, 281 and 514, respectively indicate that the models were significant. The $p$-value is less than 0.05 , indicated that the model terms were significant, values greater than 0.1 indicated that the model terms were not significant (Tab. 4).

For a dam of $10 \mathrm{~m}$ height and angle of inclination of slope $\beta=22^{\circ}$, the cohesion $c^{\prime}$ and friction angle $\varphi$ ' and dry density $\gamma_{d}$ were the terms of response surface model, $p$-value was highly significant ( $p$-value < $0.0001)$. Saturated density $\left(\gamma_{\text {sat }}\right)$ was not a significant model term ( $p$-value $>0.1)$, this was because the lowest level of water in the reservoir was $H_{w}<10 \mathrm{~m}$.
The cohesion $c^{\prime}$, friction angle $\varphi^{\prime}$, and dry density $\gamma_{d}$ had remarkable significant influence on safety factor; the results showed a positive effect of $c^{\prime}$ and $\varphi^{\prime}$ on $F s$, a reduction in these parameters could make the failure of slope of embankment.

The dry density $\gamma_{d}$ had a negative effect on $F s$ which means an important increase in this parameter could make the failure of slope of embankment, the quadratic term of cohesion $\left(c^{2}\right)$ and the cross term of $\left(c^{\prime} \varphi^{\prime}\right)$ had a negative effect on safety factor (Fig. 3a).

For a dam of $20 \mathrm{~m}$ height and angle of inclination of slope $\beta=18^{\circ}$, all inputs parameters of geotechnical proprieties and some crosses terms of $\left(c^{\prime} \varphi^{\prime}\right),\left(c^{\prime} \gamma_{d}\right)$, $\left(\varphi^{\prime} \gamma_{d}\right)$, and the quadratic term of $\left(\varphi^{\prime 2}\right)$ were the model terms which were highly significant $(p$-value $<$ 
$0.0001)$, the increase in water level of dam reservoir made saturated density $\gamma_{\text {sat }}$ a significant model term ( $p$-value $<0.05)$. The linear term of $c^{\prime}, \varphi^{\prime}$ and the cross term of $\left(\varphi^{\prime} \gamma_{d}\right)$ had a positive effect, while the linear term of $\gamma_{d}, \gamma_{\text {sat }}$ had a negative effect. One quadratic term in this case had a negative effect is the friction angle $\varphi^{\prime}$, the crosses terms of $\left(c^{\prime} \varphi^{\prime}\right),\left(c^{\prime} \gamma_{d}\right),\left(\varphi^{\prime} \gamma_{d}\right)$ had a negative effect on safety factor (Fig. 3b, 3d, 3e).

For a dam of $30 \mathrm{~m}$ height and angle of inclination of slope $\beta=16^{\circ}$. In this case, it was clear that all inputs parameters had a significant effect on safety factor. The results showed that the positive effect of co- hesion c' was remarkable for small dams $H=10 \mathrm{~m}$, this effect decreased when $H=20,30 \mathrm{~m}$ height, moreover it mentioned that the negative effect of dry density $\gamma_{d}$ and saturated density $\gamma_{\text {sat }}$ increased with the increase in dam height.

Where $H>10 \mathrm{~m}$, the friction angle $\varphi^{\prime}$ had an important effect, which means that the effect of $\varphi$ ' was predetermined by the values of $H$ and $\beta$ (Fig. 3c, 3f).

A comparison between the values of $F s$ calculated by Bishop's method and the models proposed, the relative error was less than $2 \%$ (Tab. 5). a)

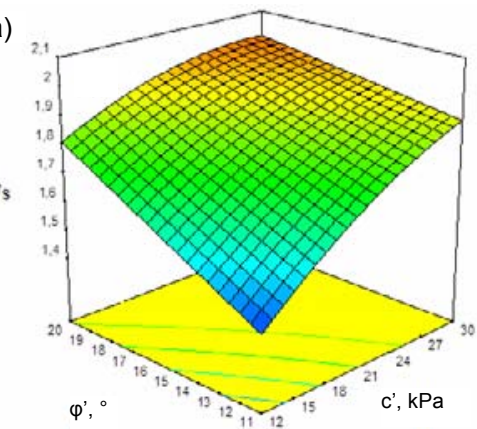

d)

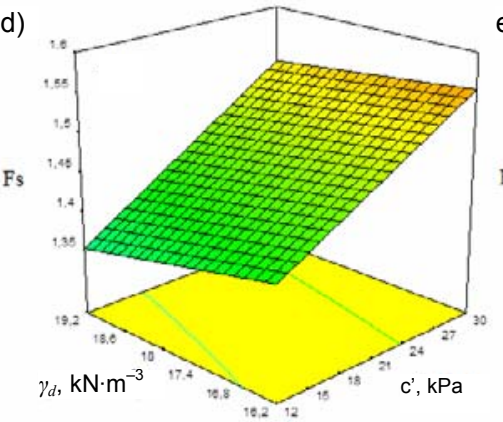

b)

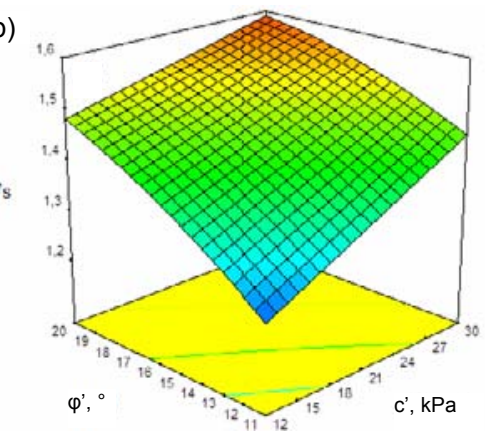

c)

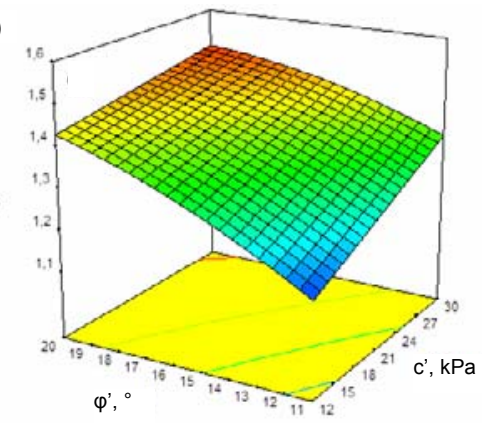

e)

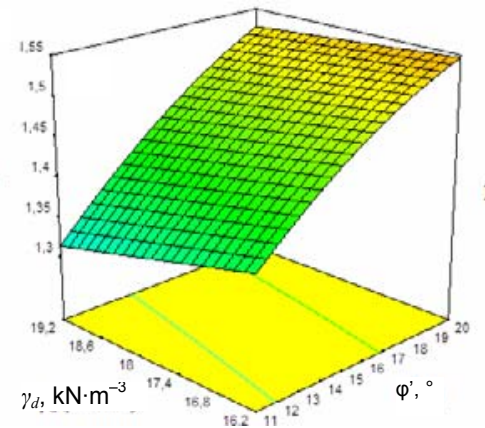

f)

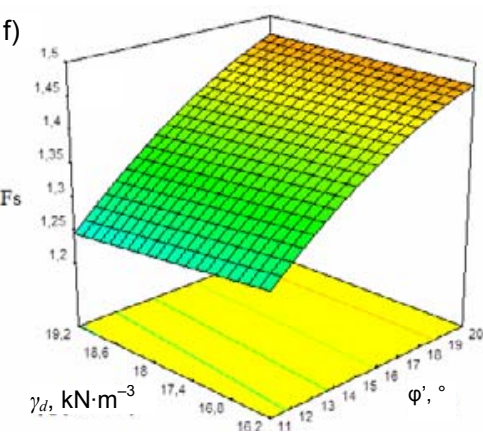

Fig. 3. 3D response surface represent the effect of tow-factors interaction on safety factor $F s$; source: own study

Table 5. Validation of the model

\begin{tabular}{|c|c|c|c|c|c|c|c|}
\hline $\begin{array}{c}\text { Hight, } \\
\text { slope }\end{array}$ & $c^{\prime}$ & $\varphi^{\prime}$ & $\gamma_{d}$ & $\gamma_{\text {sat }}$ & $\begin{array}{c}\text { Bishop's } \\
\text { method }\end{array}$ & Model & Error, \% \\
\hline $\begin{array}{c}H=10 \\
\mathrm{~m},\end{array}$ & 13 & 12 & 17 & 20.8 & 1.549 & 1.535 & 0.903 \\
\cline { 2 - 8 }$\beta=22^{\circ}$ & 16 & 17 & 18 & 20.8 & 1.807 & 1.774 & 1.826 \\
\cline { 2 - 8 } & 28 & 15 & 19 & 20.8 & 1.879 & 1.875 & 0.212 \\
\hline $\begin{array}{c}H=20 \\
\mathrm{~m},\end{array}$ & 12 & 20 & 16 & 21 & 1.282 & 1.260 & 1.716 \\
\cline { 2 - 8 }$\beta=18^{\circ}$ & 20 & 17 & 18 & 20 & 1.470 & 1.466 & 0.272 \\
\cline { 2 - 8 } $\begin{array}{c}H=30 \\
\mathrm{~m},\end{array}$ & 12 & 20 & 16 & 21 & 1.441 & 1.430 & 0.763 \\
\cline { 2 - 8 }$\beta=16^{\circ}$ & 28 & 17 & 18 & 20 & 1.372 & 1.363 & 0.655 \\
\cline { 2 - 8 } & 28 & 15 & 19 & 21 & 1.500 & 1.495 & 0.333 \\
\hline
\end{tabular}

Note: values of $F s$ calculated by Bishop's method and the models proposed.

Explanations: $c^{\prime}, \varphi^{\prime}, \gamma_{d}, \gamma_{\text {sat }}, H, \beta$ as in Table 2.

Source: own study.

\section{OPTIMIZATION AND FAILURE MODE DISCUSSION}

The response surface model developed in this study can be used to optimize the safety factor of an earth dam with respect to the values range of materials proprieties. In the long-term stability case, the dam is considered safe when the safety factor $F s=1.5$ [USACE 2003]. On other hand, it can be used to show the range values of materials proprieties if the dam is failed. In slope stability, the failure of an earth dam can be seen when the safety factor $F s \leq 1$.

GRIFFITHS [2016] discussed a several ways in which a slope can be brought to failure which are $\varphi$ ', $c$ ' reduction and $\gamma_{d}$ increase.

In the current study, using a spreadsheet in Excel based on the solver tools, the response limit state function of safety factor $F_{S}\left(c^{\prime}, \varphi^{\prime}, \gamma_{d}, \gamma_{\text {sat }}\right)$, is optimized in the first case to get the value of 1.5 with respect the range values of materials proprieties. In the second case, the safety factor is minimized to get the value of $F s \leq 1$ in which the values of materials proprieties is showed in different failures modes. Table 6 represents the results of the optimizing and minimizing work. It's clearly that in the first failure mode (reduction of $c^{\prime}$ and $\left.\varphi^{\prime}\right)$ the failure can be seen for a dam of $\left(H=10 \mathrm{~m}, \beta=22^{\circ}\right)$, because the values of $c^{\prime}$ and $\varphi^{\prime}$ is more calibrated, using the Bishop modified method the safety factor in this mode with the value of $c^{\prime}=$ $7.9 \mathrm{kPa}$ and $\varphi^{\prime}=6.8^{\circ}$ equal 1.032 is close to unity. For 
Table 6. Safety factor $(F S)$ optimization and failures mode

\begin{tabular}{|c|c|c|c|c|}
\hline \multicolumn{2}{|c|}{$F_{S}\left(c^{\prime}, \varphi^{\prime}, \gamma_{d}, \gamma_{\mathrm{sat}}\right)$} & $\begin{array}{c}H=10 \mathrm{~m} \\
\beta=22^{\circ}\end{array}$ & $\begin{array}{c}H=20 \mathrm{~m} \\
\beta=18^{\circ}\end{array}$ & $\begin{array}{c}H=30 \mathrm{~m} \\
\beta=16^{\circ}\end{array}$ \\
\hline \multirow{4}{*}{$\begin{array}{l}F s=1.5 \\
\text { All values of materials } \\
\text { proprieties respected } \\
\text { the range value used in } \\
\text { this study }\end{array}$} & $c^{\prime}, \mathrm{kPa}$ & 15.6 & 21.4 & 20.4 \\
\hline & $\varphi^{\prime}, \stackrel{\circ}{ }$ & 11 & 16.8 & 17 \\
\hline & $\gamma_{d}, \mathrm{kN} \cdot \mathrm{m}^{-3}$ & 19.2 & 17.6 & 18.56 \\
\hline & $\gamma_{\mathrm{sat}}, \mathrm{kN} \cdot \mathrm{m}^{-3}$ & 20.783 & 20 & 21 \\
\hline \multirow{2}{*}{$\begin{array}{l}\text { Reduction of } c^{\prime} \text { and } \varphi^{\prime} \\
\text { subject to } F s=1\end{array}$} & $c^{\prime}, \mathrm{kPa}$ & 7.9 & 17.6 & 16.6 \\
\hline & $\varphi^{\prime}, \stackrel{\circ}{\circ}$ & 6.8 & 5.5 & 6.8 \\
\hline \multirow{2}{*}{$\begin{array}{l}\text { Increasing of } \gamma_{d} \text { or } \gamma_{\text {sat }} \\
\text { subject to } F s=1\end{array}$} & $\gamma_{d}, \mathrm{kN} \cdot \mathrm{m}^{-3}$ & 31.8 & 40 & - \\
\hline & $\gamma_{\mathrm{sat}}, \mathrm{kN} \cdot \mathrm{m}^{-3}$ & - & - & 56.4 \\
\hline
\end{tabular}

Explanations: $c^{\prime}, \varphi^{\prime}, \gamma_{d}, \gamma_{\text {sat }}, H, \beta$ as in Table 2.

Source: own study.

other profile of $\left(H=20 \mathrm{~m}, \beta=18^{\circ}\right)$ and $(H=30 \mathrm{~m}$, $\left.\beta=16^{\circ}\right)$, the safety factor calculated by Bishop modified method equal 1 with the values of $\left(c^{\prime}=17.6 \mathrm{kPa}\right.$, $\left.\varphi^{\prime}=5.5^{\circ}\right),\left(c^{\prime}=16.6 \mathrm{kPa}, \varphi^{\prime}=6.8^{\circ}\right)$ respectively, that means that the failure can be seen if a reduction of $4 \mathrm{kPa}$ in cohesion and $11^{\circ}$ in friction angle was made from the values given the safe factor $(F s=1.5)$.

In the second failure mode (increasing of $\gamma_{d}$ ), the calibration is needed with friction angle to get the safety factor close to unity, for a dam of $(H=10 \mathrm{~m}$, $\beta=22^{\circ}$ ) the safety factor calculated by Bishop modified method equal 0.97 with the value of $\gamma_{d}=29$ $\mathrm{kN} \cdot \mathrm{m}^{-3}$ and $\varphi^{\prime}=8^{\circ}$, for a dam of $\left(H=20 \mathrm{~m}, \beta=18^{\circ}\right)$ the safety factor calculated by Bishop modified method equal 0.95 with the value of $\gamma_{d}=33 \mathrm{kN} \cdot \mathrm{m}^{-3}$ and $\varphi^{\prime}=6.9^{\circ}$, the failure can be seen and the safety factor close to unity for a dam of $\left(H=30 \mathrm{~m}, \beta=16^{\circ}\right)$ without any calibration if an important increase in $\gamma_{\text {sat }}$ is made.

\section{SUMMARY}

In this study, the design experiment methodology especially central composite design is used, to approximate the limit state function for calculating the safety factor stability of homogeneous earth dam. On other hands, to show the effect of each significant factor in the response surface.

The results show clearly that the response surface methodology is successfully used to establish a response surface that represents the functional relationship between soil properties and the safety factor, that the predicted values for three models of a dam with $10,20,30 \mathrm{~m}$ height and depth ratio $D H=1.5$, indicate the very good agreement between the response surface model and the experimental values.

The results show a positive effect of $c^{\prime}$ and $\varphi$ ' on for all three response surface models, this effect of cohesion $c$ ' it is remarkable for small dams $H=10 \mathrm{~m}$, when $H=20$ and $30 \mathrm{~m}$ height, this effect decreased, while the effect of friction angle is important when $H$ $>10 \mathrm{~m}$, an important reduction in these parameters can be made the failure of slope of embankment.
The friction angle $\varphi$ ' have an important effect where $H>10 \mathrm{~m}$, that means their effect is predetermined by the values of $H$ and $\beta$.

The effect of dry density $\gamma_{d}$ and saturated density $\gamma_{\text {sat }}$ increase with the increase in dam height, which means an important increase in these parameters can be made the failure of slope of embankment.

The relative error between the values of $F s$ calculated by Bishop's method and the models proposed is less than $2 \%$.

Two failures modes were applied using the response surface developed in this study, the results show that the failure of an earth dam can be seen if a reduction of $4 \mathrm{kPa}$ in cohesion and $11^{\circ}$ in friction angle was made from the values given the safe factor $\left(F_{S}=1.5\right)$.

\section{REFERENCES}

ALONSO E.E. 1976. Risk analysis of slopes and its application to slopes in Canadian sensitive clays. Géotechnique. Vol. 26. Iss. 3 p. 453-472.

BISHOP A.W. 1955. The use of the slip circle in the stability analysis of slopes. Géotechnique. Vol. 5. Iss. 1 p. 7-17.

CHENG Y.M., LAU C.K. 2008. Slope stability analysis and stabilization: New methods and insight. CRC Press. ISBN 9780415421720 pp. 246.

De Mello V.F.B. 1977. Reflections on design decisions of practical significance to embankment dams. Géotechnique. Vol. 27. Iss. 3 p. 281-355.

Dian-Qing L., Dong Z., Zi-Jun C., XiaO-Song T., KoKKWANG P. 2016. Response surface methods for slope reliability analysis: Review and comparison. Journal of Engineering Geology. Vol. 203 p. 3-14.

FelleniUs W. 1936. Calculation of the stability of earth dams. Transactions. $2^{\text {nd }}$ Congress on Large Dams. Washington D.C. International Commission on Large Dams of the World Power Conference. Vol. 4 p. 445462.

GEOS 2004. GEOSTAB Manual de l'utilusateur [User's manual]. GEOS Ingenieurs Conseils pp. 135.

GRIFFITHS D.V. 2016. A note on load and resistance factors in slopes and foundations. $15^{\text {th }}$ Colombian Geotechnical Congress, $2^{\text {nd }}$ International Specialization Conference of Soft Rocks. Cartagena, 5-7.10.2016.

Hammuri N., Malkawi A.H., Yamin M.M.A. 2008. Stability analysis of slope using the finite element method and limiting equilibrium approach. Bulletin of Engineering Geology and the Environment. Vol. 4 p. 80-88.

Humphreys M.P., ARMSTRONG L.W. 1993. Assessing the sensitivity of numerical models using response surface methodology. In: Proceedings of the Conference of Probabilistic Methods in Geotechnical Engineering. Canberra, Australia p. 135-144.

JANBU N. 1954. Application of composite slip surface for stability analysis. In: Proceedings of European Conference on Stability of Earth Slopes. Stockholm. Vol. 3 p. 43-49.

JANBU N. 1973. Slope stability computations. In: Embankment dam engineering: Casagrande volume. Eds. A. Casagrande, R.C. Hirschfield, S.J. Poulos, G.E. Bertram. New York. Wiley p. 47-86. 
Kostić S., Vasovic N., Jeveremovic D. 2016. Stability of earth slopes under the effect of main environmental properties of weathered clay-marl deposits in Belgrade (Serbia). Environmental Earth Sciences. Vol. 75, 492.

Lakehal R., DJemili L., Houichi L. 2011. Nomograms for calculating the safety factor of homogeneous earth dams in long-term stability. African Journal of Environmental Science and Technology. Vol. 5. No. 9 p. 755-759.

SivaKumar Babu G.L., SRIVAStava A. 2007. Reliability analysis of allowable pressure on shallow foundation using response surface method. Computers and Geotechnics. Vol. 34. Iss. 3 p. 187-194.
TANDJIRIA V., TEH C.I., LOW B.K. 2000. Reliability analysis of laterally loaded piles using response surface methods. Structural Safety. Vol. 22 p. 335-355.

Terzaghi K., PeCK R.B. 1965. Mécanique des sols appliquée aux travaux public et aux bâtiments [Soil mechanics applied to public works and buildings]. Vol. 1. Paris. Dunod pp. 565.

USACE 2003. Engineering Manual. Engineering and design: Slope stability. Washington, D.C. US Army Corps of Engineering pp. 205.

WONG F.S. 1985. Slope reliability and response surface method. Journal of Geotechnical and Geoenvironmental Engineering. Vol. 111 p. 32-53.

\section{Rida LAKEHAL, Lakhdar DJEMILI \\ Badanie wpływu zmienności głównych parametrów na stabilność jednorodnych zapór ziemnych z wykorzystaniem eksperymentu projektowego}

\section{STRESZCZENIE}

Podejście deterministyczne, takie jak metoda granicznej równowagi (LEM), szczególnie w modyfikacji Bishopa, tradycyjnie było stosowane do oceny stabilności zapór. Niepewność związana z właściwościami materiału wymusza jednak użycie metod probabilistycznych, aby ocenić wrażliwość tej niepewności na podejścia deterministyczne. W przedstawionych badaniach autorzy proponują zastosowanie eksperymentu projektowego, w szczególności metody CCD (ang. central composite design), do określenia wpływu niezależnych niepewnych parametrów na stabilność. Zastosowano wielomianowy model drugiego stopnia do utworzenia funkcji aproksymacyjnej, czyli powierzchni odpowiedzi dla zadanej powierzchni stanu, dla której dane wejściowe dostarczyły analizy jednorodnych zapór ziemnych o różnej wysokości (10, 20 i $30 \mathrm{~m}$ ), stosunku głębokości $D H=1,5$ i kolistej powierzchni poślizgu z wykorzystaniem metody granicznej równowagi w modyfikacji Bishopa. Proponowany model otrzymany w wyniku tej aplikacji reprezentuje większą dokładność prognoz. Badania wpływu parametrów geotechnicznych (właściwości materiału, z którego zbudowano wał ziemny) na czynnik bezpieczeństwa wykazały znaczenie poszczególnych czynników $\mathrm{w}$ formie zależności liniowych $\mathrm{z}$ dodatnim wpływem $c$ ' lub $\varphi$ ', ujemnym wpływem $H, \gamma_{d}, \gamma_{\text {sat }}$ i znaczącym wpływem dwuczynnikowej interakcji, w której wpływ $c$ ' był silnie uzależniony od $H, \beta, \gamma_{d}$ i $\varphi$ '. Ponadto $\varphi$ ' w dużym stopniu zależał od wartości $H$ i $\beta$. Dokonano również optymalizacji czynnika bezpieczeństwa $\mathrm{w}$ odniesieniu do szeregu właściwości materiału i przedyskutowano dwie opcje niepowodzeń - zmniejszenie $\varphi^{\prime}, c^{\prime}$ i zwiększenie $\gamma_{d}$.

Słowa kluczowe: analiza stabilności, czynnik bezpieczeństwa, eksperyment projektowy, jednorodne zapory ziemne 